\title{
EFFECTIVENESS OF SELF-HELP GROUPS IN THE IMPLEMENTATION OF LIVELIHOOD IMPROVEMENT PROGRAMS AND FOOD SECURITY IN LAMPUNG, INDONESIA
}

\author{
KORDIYANA K. RANGGA*, DAME TRULLY GULTOM, TUBAGUS HASANUDDIN AND \\ BEGEM VIANTIMALA
}

Study Program of Agricultural Extension, Faculty of Agriculture, University of Lampung, Bandar Lampung Indonesia Postcode 35141.

*Corresponding author: korrangga@yahoo.com

Submitted final draft: 25 June $2020 \quad$ Accepted: 17 August $2020 \quad$ http://doi.org/10.46754/jssm.2021.06.013

\begin{abstract}
The Community-Based Livelihood Improvement Programme (PPMK) implemented with the help of Self-Help Groups (SHG) is expected to improve the livelihoods of poor people. This study aims to analyse: 1) the effectiveness of SHG in the implementation of PPMK programmes, 2) food security of SHG member households, and 3 ) the relationship between the effectiveness of PPMK programme implementation and SHG member food security. The study was conducted at Margodadi Village, Metro City in October-December 2018. The research method used involved a survey with a quantitative approach with saturation sampling techniques. Respondents were $25 \mathrm{SHG}$ members who were recipients of aid under the PPMK programme. A descriptive analysis method was used to answer the first and second objectives, while the non-parametric statistic of Spearman's Rank correlations was used to answer the third objective. The results showed that:

1) SHG members were effective in implementing the PPMK programme with a rating in the "good" category, with all the overall programme objectives being achieved, helping to increase the income of SHG member households, strengthening SHG's institutional capacity and the ability of SHG members to expand their business;

2) the food security level of the majority of SHG member households in Margodadi Village was both objectively and subjectively in high category; and

3) the effectiveness of SHG in the PPMK was significantly different from the level of household food security.
\end{abstract}

Keywords: Group effectiveness, program, food security, household.

Abbreviations: [Effectiveness of Self-Help Groups in Lampung Indonesia].

\section{Introduction}

Poverty is a problem that is still faced by many developing countries, including Indonesia (Suryahadi, Suryadarma, \& Sumarto, 2009; Alatas, Banerjee, Hanna, Olken, \& Tobias, 2012; Sumner \& Edward, 2014). Many factors cause poverty including: a lack of natural resources (Hassan, Zaman, \& Gul, 2015), a lack of human resources (Roca-puig, Beltrán-martín, \& García-juan, 2019), low education levels (Buck \& Deutsch, 2014; Mihai \& Manea, 2015), and the lack of available jobs (Siwar et al., 2016; Sri \& Suliswanto, 2010). This condition causes helplessness in the community to face economic hardships, such as the weakness of the small- and-medium business sector (Dartanto, 2013; Rangga \& Syarief, 2018).

One of the community empowerment programmes used to alleviate poverty and expand employment opportunities in urban areas is the National Urban Independent Community Empowerment Programme (PNPM-MP) (Fatriadi, Asteriani, \& Cahyaningsih, 2017; Soesanta, 2013)so that sustainability will be difficult if not prepared right formula. This paper also examines some of the things that occurred starting from the history of poverty alleviation programs in Indonesia, until the emergence of a national program priorities under the PNPM Mandiri (Rural and Urban. 
This National Programme aims to support the government's efforts to reduce the number of poor people in Indonesia and is expected to improve the welfare of Indonesian communities according to the mandate of the UUD' 45. The strategy implemented by the programme involves strengthening community institutions and engaging elements of the community, right from the planning stage, through to the implementation, monitoring and evaluation stages (Mubarak, 2010; Yamsul \& Salim, 2013; Mufid, 2014; Yanfika, Listiana, Mutolib, \& Rahmat, 2019).

There are three programmes run by PNPM-MP comprising physical, economic and social development schemes (Soesanta, 2013; Munawar, 2017). On the economic side, the poor can avail of a revolving economic loan assistance facility (Matridi et al., 2015; Rahjuni, Badriah, \& Rafinda, 2019). Revolving loans are provided to assist productive activities in order to create business and employment opportunities, and can also be used to start schemes that improve community welfare (Fatriadi et al., 2017). Revolving loans to the poor are given directly to the community through Non Governmental Organisations (NGO) in each village in various regions, including Metro City in Lampung Province. The NGO is an institution established to expedite the running of the PNPM-MP programme under the purview of the Financial Management Unit (UPK), which will consider the feasibility of the community loan.

Metro City has 22 NGO's, slightly fewer than other regions, which have two NGO's with a "civilized" status, the highest status, for the Community-Based Livelihood Improvement Programme (PPMK). The programme is a part of the Urban Independent Empowerment programme (PNPM) which is devoted to the development of manufacturing and production activities that have received revolving economic loans with returns of up to $98 \%$. The PPMK scheme uses the same principles as revolving economic loans, the only differences being the amount of funds loaned are higher than revolving loans and the period of repayment being longer.
Through the mentoring approach to SelfHelp Groups (SHG), the PPMK is expected to improve the livelihoods of the poor, particularly with regard to the income levels which ultimately impacts the level of household food security (Meilia, Zakaria, \& Prasmatiwi, 2014; Rangga, Darsono, Anantanyu, \& Wijaya, 2014).

However, if a programme that aims to help the community prosper is not adopted and accommodated properly by the target audience that is supposed to benefit from it, problems such as the misuse or abuse of the programme and inappropriate implementation may occur.

Research on the effectiveness and impact of the Self-help Groups has proven that they have a good impact on society (Mehta, Mishra, \& Amrinder Singh, 2011; Hartina et al., 2017; Gugerty, Biscaye, \& Anderson, 2018; Nimisha \& Arumugam, 2019).

However, research on the relationship between SHGs and household food security has not been studied at any length and is something that this research paper aims to rectify. This research is very interesting and expected to provide new findings that will aid efforts to improve global food security, especially for the poor in both urban and rural areas.

The success of the SHG-run programme is expected to support enhancement of food security initiatives and Sustainable Development Goals in Indonesia.

Based on this, it is necessary for research to analyse:

1) The effectiveness of SHG in the implementation of the PPMK in Margodadi Village, Metro City,

2) the food security of SHG member households, and

3) the relationship between the effectiveness of SHG and the food security of SHG members.

\section{Materials and Methods}

The research site was Margodadi Village, Metro 
City in Lampung Province, Indonesia. The site was determined using a purposive sampling method with the consideration that Margodadi Village was the only village in Metro City with an NGO that received the PNPM Award from the Mayor of Metro City. Data collection and research were conducted in October-December 2018.

The sampling technique in the study used saturation sampling technique. Saturation sampling is a sample determination technique using population members as samples. The study population came from members of the Non-Governmental Organisation in LKM (Community Self-help Organization) of Metro City who were recipients of the PPMK. The method of analysis was carried out using descriptive analysis and nonparametric statistics. Descriptive analysis was used to answer the first and second objectives, while the third objective was obtained by using non-parametric analysis of Spearman's rank correlation (Nichols \& Holmes, 2007; Henseler, 2012; Fujita, Takahashi, \& Patriota, 2014).

The effectiveness of SHG in implementing the PPMK can be seen from the large increase in the income of SHG members, the improvement of institutional capacity, and the ability to expand the business. The level of household food security is known by using objective and subjective measures. Objective measures are derived by comparing the food expenditure and total household expenditure. If the share rate of food expenditure in household is $<60 \%$, then the household is said to have food security, and if the share rate of food expenditure is $\geq 60 \%$, then the household is said not to have food security (Sapar, Jahi, Ilham, \& Bonar, 2007).
The subjective food security of SHG member households in this study was seen from the opinions, views, attitudes, or arguments of SHG member households on their food situation, namely the availability of food for SHG household members, household food distribution, and consumption of food items to meet the food needs of its members from time to time in order to live a healthy life and be able to carry out their daily activities.

\section{Results and Discussion}

\section{Responden Identity}

The majority of SHG members $(68 \%)$ are women. The results of field observations revealed that the types of businesses pursued by SHG members $(72 \%)$ were mostly various foods (various chips: bananas, cassava), and stalls that were easy to set up and run by women (mothers), while things related to fisheries business, namely fish spawning and catfish farming activities were carried out by men (fathers).

The productive age allows respondents to have high morale and good understanding of the material. This condition is one of the potentials to increase the active role of SHG members to get involved in the PPMK. The higher a person's age, the better his performance will be (Nurhardjo, 2012; Sapar, Yusuf, \& Haedar, 2014; Mutolib, Yonariza, Mahdi, \& Ismono, 2016) West Sumatra Province in Indonesia, \nleads to the clan's women experiencing injustice when

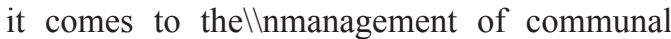
forest land (ulayat. This shows a maturity owned by each individual in order to determine the decision-making and concrete steps in the future in doing a business. The details of the respondents in this study is presented in Table 1. 
Table 1: Identity of Self-Help Groups (SHG) based on age, formal education, and number of dependent family members

\begin{tabular}{|c|c|c|c|}
\hline No & Variable & $\begin{array}{l}\text { Number } \\
\text { (Persons) }\end{array}$ & Percentage $(\%)$ \\
\hline \multirow[t]{4}{*}{1} & Gender & & \\
\hline & Male & 8 & 32.00 \\
\hline & Female & 17 & 68.00 \\
\hline & Total & 25 & 100.00 \\
\hline \multirow[t]{5}{*}{2} & Age (years) & & \\
\hline & (1) Young (28-41) & 13 & 52.00 \\
\hline & (2) Adult (42-55) & 9 & 36.00 \\
\hline & (3) Old (56-66) & 3 & 12.00 \\
\hline & Total & 25 & 100.00 \\
\hline \multirow[t]{5}{*}{3} & Formal Education & & \\
\hline & (1) Elementary School & 6 & 24.00 \\
\hline & (2) Junior-Senior High School & 18 & 72.00 \\
\hline & (3) Diploma & 1 & 4.00 \\
\hline & Total & 25 & 100.00 \\
\hline \multirow[t]{5}{*}{4} & $\begin{array}{l}\text { Number of dependent family } \\
\text { members(person) }\end{array}$ & & \\
\hline & (1) 2 & 5 & 20.00 \\
\hline & (2) 3 & 8 & 32.00 \\
\hline & (3) 4 & 12 & 48.00 \\
\hline & Total & 25 & 100.00 \\
\hline \multirow[t]{5}{*}{5} & Type of business & & \\
\hline & (1) Fisheries & 7 & 28.00 \\
\hline & (2) Various foods & 13 & 52.00 \\
\hline & (3) Stall & 5 & 20.00 \\
\hline & Total & 25 & 100.00 \\
\hline
\end{tabular}

\section{An Overview of PPMK and SHG}

PPMK is an intervention programme under the PNPM-MP established by the Ministry of Public Works of the Republic of Indonesia, to develop its manufacturing and business activity levels. The PPMK aims to strengthen SHG institutional and business activities and make them more independent and sustainable, which are oriented to improving the livelihoods of the poor (sustainable livelihood) with a group assistance approach. SHG are groups of people who voluntarily unite over a shared vision, interest or need. The group works together to achieve the same goals. The PPMK in Metro City began on August 6, 2014, at KSM (Community SelfReliance Institution) of Margodadi Jaya. The program consists of the preparation, planning, disbursement, and utilisation stages, as well as the strengthening and development stages. Before the programme started running, KSM, SHG, and city facilitators met and continued to meetas much as eight times between the preparation stage and the planning stage of the programme. 


\section{Effectiveness of SHG Members in the Implementation of the PPMK}

The effectiveness of SHG in implementing the PPMK can be seen by the magnitude of the success of the PPMK in achieving its goals, which include: increasing the income of SHG members after participating in the PPMK, increasing institutional capacity, and the ability of SHG members to expand their businesses. The results of the study related to the effectiveness of SHG in running the PPMK is displayed in Table 2.

From Table 2, information it can be seen that most respondents considered the PPMK as capable of boosting member income $(52.00 \%)$, strengthening institutional capacity $(44.00 \%)$, and being able to increase the ability of members to expand their businesses $(36.00 \%)$.

\section{Increasing of SHG Members income}

There was an increase in the total income of SHG members after participating in the PPMK program (Table 3 ). The highest percentage of income was obtained by SHG Sembada members, with 211 percent. SHG Sembada is one of the SHGs that is involved with fish hatchery businesses. This significant increase in income is due to SHG Sembada having a business that always runs smoothly (has continuous production), a large initial capital from SHG members, a demand for catfish seeds that always increases every season and a ready availability of PPMK loans, which has allowed SHG Sembada to increase its capital and expand its marketing activities exponentially.

On the other end of the spectrum lies SHG Kenanga, an SHG which has the majority of its members working as small traders (selfemployed) who do not require large loans or

Table 2:Effectiveness of SHG Members in the Implementation of the PPMK

\begin{tabular}{|c|c|c|c|}
\hline No & Variable (Score) & $\begin{array}{l}\text { Number } \\
\text { (Person) }\end{array}$ & $\begin{array}{c}\text { Percentage } \\
(\%)\end{array}$ \\
\hline \multirow[t]{6}{*}{1} & Increase in income of SHG members & & \\
\hline & $2,000-3,325$ (Less increased) & 6 & 24.00 \\
\hline & 3,326-4,651 (Quite increased) & 6 & 24.00 \\
\hline & $4,652-5,975$ (Increased) & 13 & 52.00 \\
\hline & Total & 25 & 100.00 \\
\hline & Average: 4,560 (Quite increased) & & \\
\hline \multirow[t]{6}{*}{2} & Strengthening institutional capacity & & \\
\hline & 8,400-- 12,306 (Bad) & 7 & 28.00 \\
\hline & 12,307--16,213 (Fairly good) & 11 & 44.00 \\
\hline & $16,214--20,120($ Good $)$ & 7 & 28.00 \\
\hline & Total & 25 & 100.00 \\
\hline & Average: 14.513 (Fairly good) & & \\
\hline \multirow[t]{6}{*}{3} & The ability of members to expand business activities & & \\
\hline & $2,000-3,255$ (Less capable) & 8 & 32.00 \\
\hline & 3,256-4,511 (Quite capable) & 8 & 32.00 \\
\hline & 4,512-5,767 (Capable) & 9 & 68.00 \\
\hline & Total & 25 & 100.00 \\
\hline & Average: 4.005 (Quite capable) & & \\
\hline
\end{tabular}


start up capital. This SHG sells raw/cooked vegetables, various chips, market snacks, and grocery store items. After a PPMK loan, SHG members can increase their income by more than 50 percent. The increased revenue details can be seen in Table. 3 .

\section{Strengthening SHG Institutional Capacity}

Strengthening institutional capacity of SHG in question is an increase in the ability of groups to understand the rules and carry out development sustainably in a broad sense, which consists of norms/regulations implemented as well as facilities and technology owned by SHG members. Strengthening institutional capacity of SHG includes:

1) Utilisation of loan capital,

2) Loan instalments,

3) Appropriateness of instalment payment times,

4) Reporting on the utilisation of loan funds,

5) Ownership of facilities and technology,

6) Computer-use in SHG administration management, and

7) Internet use in accessing information.

Institutional capacity strengthening of SHG members (44\%) is in a fairly good category. The results showed that in the use of loan capital, SHG members were quite cooperative, most of which used loan capital only for businesses, not used for other purposes outside the business.

\section{Ability of SHG Members to Expand Business Activities}

The level of ability of SHG members to expand their businesses is can be seen from: the increase in the types of businesses run by SHG members and the increase in the volume of business conducted. The level of ability of SHG members to expand their businesses was in the mostly capable category at $68 \%$, yet the average level of ability of SHG members was in the category of "quite capable". The ability of SHG members to expand their businesses can be seen in Table 4 .

The increase in the type of business carried out by SHG members showed that nine people decided to continue to have one type of business, because they wanted to focus on developing the business. All SHG members who only carried out one type of business, namely SHG Sembada with its catfish hatchery business, sought to increase the number volume of business transactions, even though the type of businesses owned was only one. Unlike members of SHG Kenanga, Tunas Karya, and Kenari, whose entrepreneurs and traders wanted to add many different types of businesses. Irrespective of the types of businesses owned, all SHG members experienced an increase in business volumes at one time or another, with the average business volume increase being more than 50 percent. This is due to the high demand. This condition proves that the NGO's have been effective in implementing the PPMK, by increasing members' income, strengthening institutional

Table 3: Average income and increased income of SHG members before and after participating in the PPMK program.

\begin{tabular}{|c|c|c|c|c|}
\hline \multirow[t]{2}{*}{ No. } & \multirow[t]{2}{*}{ Name of SHG } & \multicolumn{2}{|c|}{$\begin{array}{l}\text { Average Income of SHG Members } \\
\text { (Rupiah per Month) }\end{array}$} & \multirow{2}{*}{$\begin{array}{c}\text { Percentage of Increase in Income of } \\
\text { SHG Members (\%) }\end{array}$} \\
\hline & & Before & After & \\
\hline 1 & Matahari & 1.290 .000 & 2.614 .000 & 102 \\
\hline 2 & Sembada & 1.700 .000 & 5.292 .800 & 211 \\
\hline 3 & Tunas Karya & 1.000 .000 & 2.020 .000 & 102 \\
\hline 4 & Kenanga & 1.300 .000 & 2.150 .000 & 65 \\
\hline 5 & Kenari & 1.290 .000 & 2.300 .000 & 78 \\
\hline Total & & 6.580 .000 & 14.376 .800 & \\
\hline
\end{tabular}


Table 4: Expansion of SHG member business activities per person

$\begin{array}{cl}\text { No } & \begin{array}{c}\text { Name of } \\ \text { Self-Help } \\ \text { Group }\end{array} \\ 1 & \text { Matahari } \\ 2 & \text { Sembada } \\ 3 & \text { Tunas karya } \\ 4 & \text { Kenari } \\ 5 & \text { Kenanga } \\ & \text { Total }\end{array}$

capacity, and the ability of SHG members to expand their businesses; a clear signal that the overall programme objectives have been wellachieved.

\section{Household Food Security of SHG Members}

Food Security according to Law no. 18 of 2012 is the condition of the fulfillment of food for the State up to individuals and reflected in the availability of sufficient food both in quantity and quality, safe, diverse, nutritious, evenly distributed and affordable and not in conflict with the religion, beliefs and culture of the community in order to be able to live healthy, active and productive in a sustainable manner.

Subjective food security is measured based on the views, opinions, and attitudes of the people in affected by the situation and involves three indicators, namely the availability of food, the distribution of food and the level of consumption of food. While objectively, food security is based on the amount of food in general, energy consumption, per-capita food availability, the share of household food expenditure on total household expenditure and household ability to deal with shocks.

\section{Level of Household Food Security of SHG Members Objectively}

The level of food security objectively can be seen from the share of household food expenditure. Household expenditure is the costs incurred by a household to fulfill their living needs. Household expenditure is divided into expenditures for food and non-food expenditure. Household expenditure of SHG members was dominated by non-food expenditure, with average of IDR1,918,186 per month $(66.35 \%)$, while the remaining 33.64 percent was spent for food expenditure. Food expenditure of SHG member households is generally used to meet basic food needs, while non-food expenditure was dominated by expenses for home furniture, education, and fuel. The share of low food expenditure indicates that objectively most households (96\%) had food security.

Household income was in the high category (Table 6). This is in accordance with Engel's coefficient, which states the proportion of money spent on food in household expenses falls as a country's economic growth makes its people wealthier, and tends to rise when they get poorer (Sapar et al., 2007), so that the higher the income, the lower the share of food expenditures incurred. Share Rate of food expenditure for SHG member households in Margodadi Village displayed in Table 6 .

\section{Level of Household Food Security of SHG Members in Margodadi Village Subjectively}

There are three aspects that are used in the food security of SHG member households subjectively, namely: aspect of household food availability, aspect of household food distribution, and aspect of household food consumption (Table 7). 
Table 5:Expenditure for food and non-food stuff of SHG members household in Margodadi Village of 2016

\section{Types of Food Expenditure}

Flour and grains

Cassava

Oil and fat

Animal food

Vegetable food

Fruit /oily seeds

Nuts

Sugar

Colored vegetables

Colorless vegetables

Fruit vegetables

Fruit

Seasonings

Beverage

Amount of food expenditure

Expenditure Type

Non-Food

Health

Education

Electricity

Phone/cell phone

Home Furniture

House reparation

Clothes

Goods and services

Fuel

Transportation

Social

Tax

Body cleanliness

Cosmetics

Amount of Non-Food Expenditure

Amount of Household Expenditures

\section{Average Expenditure}

(IDR/month)

268.120
14.360
32.880
133.300
72.460
26.860
18.740
36.560
113.960
12.380
$161.587,5$
66.460
21.840
25.220
$972.527,5$

Average Expenditure (IDR/month)

$\begin{array}{rc}22.840 & 0.79 \\ 232.580 & 8.05 \\ 98.496 & 3.41 \\ 69.800 & 2.41 \\ 895.792 & 30.99 \\ 19.800 & 0.68 \\ 151.880 & 5.25 \\ 116.200 & 4.02 \\ 178.400 & 6.17 \\ 5.200 & 0.06 \\ 5.200 & 0.18 \\ 24.354 & 0.84 \\ 40.836 & 1.41 \\ 62.008 & 2.15 \\ 1.918 .186 & 66.35 \\ .890 .713,5 & 100,00\end{array}$

\section{Percentage (\%)}

9.28

0.50

1.14

4.61

2.51

0.93

0.65

1.26

3.94

0.43

5.59

2.30

0.76

0.87

33.64

Percentage (\%)

.79

0.06

.15

$2.890 .713,5$

. 
Table 6: Share rate of food expenditure of SHG member households in Margodadi Village

\begin{tabular}{|c|c|c|c|}
\hline Share Rate of Expenditure & Classification & Number & Percentage (\%) \\
\hline RT $<60 \%$ & $\begin{array}{c}\text { Have Food Security } \\
\text { Does Not Have Food } \\
\text { RT } \geq 60 \%\end{array}$ & 24 & 96.00 \\
\hline Number & 1 & 25 & 4.00 \\
\hline
\end{tabular}

Table 7: The level of household food security of SHG members subjectively of 2017.

No

Sub-variable (Score)

$1 \quad$ Food Availability Level

7.431-9,926 (Low)

3.326-4,651 (Medium)

12.423-14.916 (High)

Total

Average: 11.121 (Medium)

2 Food Distribution Level

$10.193-12.498$ (Low)

$12.499-14.804$ (Medium)

$14.805-17.108$ (High)

Total

Average: 13.415 (Medium)

3 Food consumption level

13.477 - 17.014 (Low)

$17.015-20.552$ (Medium)

$20.553-24.089$ (High)

Total

Average: 18.725 (Medium)

4. Recapitulation of Food Security Subjectively

$$
\begin{aligned}
& 31.476-38.092 \text { (Low) } \\
& 38.093-44.709 \text { (Medium) } \\
& 44.710-51.324 \text { (High) } \\
& \text { Total }
\end{aligned}
$$

Average $=43.260$ (Medium)

$\begin{array}{cr}\begin{array}{l}\text { Number } \\ \text { (person) }\end{array} & \begin{array}{l}\text { Percentage } \\ \text { (\%) }\end{array} \\ & \\ 8 & 32.00 \\ 10 & 40.00 \\ 7 & 28.00 \\ 25 & 100.00\end{array}$

10

40.00

$8 \quad 32.00$

$7 \quad 28.00$

$25 \quad 100.00$

$\begin{array}{cc}6 & 24.00 \\ 12 & 48.00 \\ 7 & 28.00 \\ 25 & 100.00\end{array}$

100.00

8.00

$\begin{array}{ll}15 & 60.00 \\ 8 & 32.00\end{array}$

100.00

a. Aspect of Household Food Availability of SHG Members

The food security level of SHG member households in Margodadi Village based on the aspect of food availability was in the "medium" category with an average value of 11,121 which means that the SHG member households food was sufficient to fulfill their household food needs. Based on the conditions that occured in the field, it 
was concluded that the conditions of food availability for SHG member households mostly tended to be "fairly good" and the food was available in sufficient quantities to meet the needs of all SHG member households.

b. Aspect of Household Food Distribution of SHG Members

The household food distribution was in the classed as "medium", with an average value of 13.415, which meant that the distribution of food in SHG member households was "fairly good". Given the data collected from respondents, it is clear that the accessibility and affordability of food for SHG member households was easily accessible. This is because only a small portion of food needed by SHG member households purchased, the rest is self-produced.

\section{c. Aspects of Household Food Consumption of SHG Members}

The food security level of SHG member households from the aspect of household food consumption was "medium" with an average value of 18,725 . The results of field observations showed that the knowledge of SHG members regarding the food needed was of the right composition and type. Additionally, the food consumed was "fairly good" for health, however, the majority of SHG members still did not consider the quality of the food being consumed.

Generally SHG members only consume food as it is according to what suits their tastes without any particular consideration to the quality of the food being consumed.

The result of the recapitulation and observation of the food security of SHG member households in Margodadi Village was in the Medium category with an average value of 43,260 which means that SHG member households in Margodadi Village have sufficient food security. This is because the aspect of food availability of SHG member households and aspects of food distribution of SHG member households were in the "medium" at best.

\section{The Relationship between the Effectiveness of SHG in the PPMK and the Level of Household Food Security of SHG Members}

The relationship between the effectiveness of SHG in the PPMK program and the level of food security of SHG member households using the Sperman's Rank correlation analysis showed a significance value of 0.017 . This value was smaller than the $\alpha$ value of 0.05 or at confidence level of $95 \%$, which means that there is a significant difference between the effectiveness of SHG in the PPMK and the level of food security of SHG member households in Margodadi Village.

Based on the results of the research above, it can be concluded that the more effective SHG in the PPMK, the higher the level of food security of SHG members in Margodadi Village. The success of the community based PPMK is supported by many factors such as ongoing assistance, and social capital that has been owned by the community (willingness and commitment of the target community).

In other regions, the implementation of PPMK may not be the same as the PPMK in Metro City because it is influenced by several factors. The scope of this research is small, namely at the village level, but the success of the PPMK in Metro City is an indication that this program has the potential to be replicated in other regions to realise food security and community-based independence. The food security programme is very important, especially in poor communities where the level of food security is low.

\section{Conclusion}

The effectiveness of SHG members implementing the PPMK was "good" with the overall objective of the programme being achieved, namely the increase in the income of SHG member households, the strengthening of institutional capacity of SHG was "fairly good", and the ability of SHG members to expand their 
businesses was "quite capable". The level of household food security of SHG members in Margodadi Village objectively shows that the majority of households were in high level of food security.

The effectiveness of SHG in the PPMK was significantly different from the level of household food security, with a correlation coefficient of 0.017 and a confidence level of $95 \%$. This result indicates that the more effective the programme gets, the higher the level of household food security of SHG members becomes.

Based on the Global Food Security Index assessment in 2018, Indonesia is in the 65th position out of 113 countries. In 2019, the number of poor people in Indonesia was 24.79 million people. This research provides positive findings to improve food security and reduce poverty in Indonesia. Increasing food security and poverty alleviation must be following the capacity and character of the community. Therefore the approach through SHG is considered appropriate to overcome the problem of food security and poverty.

\section{Acknowledgements}

The authors extend their gratitude to reviewers for critical comments on the manuscript and the university for the research opportunity.

\section{References}

Alatas, V., Banerjee, A., Hanna, R., Olken, B. A., \& Tobias, J. (2012). Targeting the poor: Evidence from a field experiment in Indonesia. American Economic Review, 102(4), 1206-1240. http://doi.org/10.1257/ aer.102.4.1206

Buck, R., \& Deutsch, J. (2014). Effects of poverty on education. Internationa Journal of Human Sciences, 11(2), 1139-1148. http://doi.org/10.14687/ijhs.v11i2.3043

Dartanto, T. (2013). Reducing fuel subsidies and the implication on fiscal balance and poverty in Indonesia: A simulation analysis.
Energy Policy, 58, 117-134. http://doi. org/10.1016/j.enpol.2013.02.040

Fatriadi, R., Asteriani, F., \& Cahyaningsih, C. (2017). Effectiveness of the National Program for Community Empowerment (PNPM) for infrastructure development accelerated and geoplanology in district of Marpoyan Damai, Pekanbaru. Journal of Geoscience, Engineering, Environment, and Technology, 2(1), 53-63. http://doi. org/10.24273/jgeet.2017.2.1.30

Fujita, A., Takahashi, D. Y., \& Patriota, A. G. (2014). Anon-parametric method to estimate the number of clusters. Computational Statistics \& Data Analysis, 73, 27-39. http:// doi.org/10.1016/j.csda.2013.11.012

Gugerty, M. K., Biscaye, P., \& Anderson, C. L. (2018). Delivering development? Evidence on self-help groups as development intermediaries in South Asia and Africa. Development Policy Review, 37(1), 129151. http://doi.org/10.1111/dpr.12381

Hartina, S., Djaelangkara, R., Studi, P., Publik, A., Tadulako, U., \& Makassar, U. N. (2017). Pinisi discretion review analysis of the setting agenda of non-smoke areas in Sigi Regency. Pinisi Discretion Review, 1(1), 31-38.

Hassan, S. A., Zaman, K., \& Gul, S. (2015). The relationship between growth-inequalitypoverty triangle and environmental degradation: Unveiling the reality. Arab Economics and Business Journal, 10(1), 57-71. http://doi.org/10.1016/j. aebj.2014.05.007

Henseler, J. (2012). PLS-MGA: A nonparametric approach to partial least squaresbased multi-group analysis. In W. Gaul, A. Geyer-Schulz, L. Schmidt-Thieme, \& J. Kunze (Eds.), Challenges at the interface of data analysis, computer science, and optimization (pp. 495-50). Springer: Berlin, Heidelberg. http://doi.org/10.1007/978-3642-24466-7-50 
Matridi, R. A., Zuraidi, D., Setyadiharja, R., Sanopaka, E., Effendi, D., \& Utari, D. S. (2015). An evaluation of P3DK ( An Acceleration of Development Village Program ): A reviewing on failure toward revolving loan fund system in Kepulauan Riau Province, Indonesia. Procedia - Social and Behavioral Sciences, 169(August 2014), 189-197. http://doi.org/10.1016/j. sbspro.2015.01.302

Mehta, S. K., Mishra, H. G., \& Amrinder Singh. (2011). Role of self help groups in socio-economic change of Vulnerable poor of jammu region. In 2011 International Conference on Economics and Finance Research (Vol. 4, pp. 519-523). Singapore. Retrieved from http://ipedr.com/ vol4/103-F10147.pdf

Meilia, A., Zakaria, W. A., \& Prasmatiwi, F. E. (2014). Ketahanan pangan rumah tangga petani kopi di Kabupaten Lampung Barat. Jurnal Ilmu-Ilmu Agribisnis, 2(2), 133-141.

Mihai, M., \& Manea, D. (2015). Education and poverty. Procedia Economics and Finance, 32(15), 855-860. http://doi.org/10.1016/ S2212-5671(15)01532-4

Mubarak, Z. (2010). Evaluasi pemberdayaan masyarakat ditinjau dari proses pengembangan kapasitas dapa kegiatan PNPM mandiri perkotaan. [Thesis Magister Teknik Pembangunan Wilayah dan Kota UNDIP, Semarang. Universitas Diponegoro].

Mufid, A. (2014). Sistem pendukung keputusan penilaian proposal kegiatan PNPM MPd menggunakan metode Profile Matching dan Analytic Hierarchy Process (AHP). Jurnal Sistem Informasi Bisnis, 4(1), 40-45. http:// doi.org/10.21456/vol4iss 1pp40-47

Munawar, N. (2017). Institutional Analysis on National Program for Community Empowerment of Independent Urban (PNPM-MP) for poverty reduction. Arts and Social Sciences Journal, 8(1), 1-6. http://doi.org/10.4172/2151-6200.1000248
Mutolib, A., Yonariza, Mahdi, \& Ismono, H. (2016). Gender inequality and the oppression of women within minangkabau matrilineal society: A case study of the management of ulayat forest land in nagari bonjol, dharmasraya district, west sumatra province, Indonesia. Asian Women, 32(3), 23-49.

Nichols, T., \& Holmes, A. (2007). Nonparametric procedures. In K. Friston, J. Ashburner, S. Kiebel, T. Nichols, \& W. Penny (Eds.), Statistical parametric mapping (pp. 253-272). Cambridge, Massachusetts: Elsevier Ltd. All rights reserved. http://doi.org/10.1016/B978012372560-8/50021-8

Nimisha, M., \& Arumugam, D. (2019). Impact of self-help groups on self, social awareness and economic empowerment of women entrepreneurs of Coimbatore District. International Journal of Engineering and Advanced Technology, 8(5), 10071014. Retrieved from https://www.ijeat. org/wp-content/uploads/papers/v8i5/ E7076068519.pdf

Nurhardjo, B. (2012). Karakteristik dan kinerja buruh wanita pada Gudang Tembakau Gmit di Kecamatan Panti Kabupaten Jember. Jurnal Bisnis dan Manajemen, 6(1), 55-68.

Rahjuni, D., Badriah, L. S., \& Rafinda, A. (2019). Implementing productive economic activities for the poor based on social capital. SEA - Practical Application of Science, 7(19), 47-54.

Rangga, K. K., Darsono, Anantanyu, S., \& Wijaya, M. (2014). The participation of micro business affinity group members in the implementation of food self-sufficiency action program in Lampung Province. Academic Research International, 5(3), 112-122.

Rangga, K., \& Syarief, Y. (2018). Paddy farmer households' participation and food security level in special effort program in Seputih Raman sub-district of Central Lampung Regency Paddy farmer households' 
participation and food security level in special effort program in Seputih Raman s. IOP Conference Series: Earth and Environmental Science, 142(012060), 1-5.

Roca-puig, V., Beltrán-martín, I., \& Garcíajuan, B. (2019). Incorporating poverty in society into strategic human resource management. The International Journal of Human Resource Management, O(0), 1-24. http://doi.org/10.1080/09585192.2019.164 0764

Sapar, S., Jahi, A., Ilham, N., \& Bonar, D. a N. (2007). Penggunaan pangsa pengeluaran pangan sebagai indikator komposit ketahanan pangan. SOCA (Socio-Economic of Agriculturre and Agribusiness), 7(3), $1-22$.

Sapar, Yusuf, M., \& Haedar. (2014). Hubungan kinerja penyuluh pertanian dengan kompetensi petani kakao dalam peningkatan produktivitas kakao di Kota Palopo, Kabupaten Luwu, Luwu Utara dan Luwu Timur. Jurnal Ekonomi Pembangunan, 01(02), 67-76. http://doi.org/2339-1529

Siwar, C., Ahmed, F., Zahari, S. Z., Idris, N. D. M., Mia, M. S., \& Bashawir, A. (2016). Poverty mapping and assessing the relationship between poverty and sociodemographic characteristics of households: A study in Kelantan, Malaysia. Journal of Environmental Science and Technology, $9(6), \quad 407-416 . \quad \mathrm{http}: / /$ doi.org/10.3923/ jest.2016.407.416

Soesanta, P. E. (2013). Penanggulangan kemiskinan melalui Program Nasional Pemberdayaan Masyarakat (PNPM) mandiri perdesaan. Jurnal Bina Praja, 5(2), 73-78. http://doi.org/http://dx.doi. org/10.21787/jbp.5.2013.73-78
Sri, M., \& Suliswanto, W. (2010). Pengaruh Produk Domestik Bruto (Pdb) dan Indeks Pembangunan Manusia (Ipm) terhadap angka kemiskinan di Indonesia. Jurnal Ekonomi Pembangunan, 8(2), 356-366. http://doi.org/10.22219/JEP.V8I2.3610

Sumner, A., \& Edward, P. (2014). Assessing poverty trends in Indonesia by international poverty lines. Bulletin of Indonesian Economic Studies, 50(2), 207-225. http:// doi.org/10.1080/00074918.2014.938404

Suryahadi, A., Suryadarma, D., \& Sumarto, S. (2009). The effects of location and sectoral components of economic growth on poverty: Evidence from Indonesia. Journal of Development Economics, 89(1), 109-117. http://doi.org/10.1016/j. jdeveco.2008.08.003

Yamsul, P., \& Salim, U. (2013). The influence of motivation and organization culture on work satisfaction and organizational commitment (Study on National Society Empowerment Program in Southeast Sulawesi Province). International Journal of Business and Management Invention ISSN (Online, 2(9), 18-25.

Yanfika, H., Listiana, I., Mutolib, A., \& Rahmat, A. (2019). Linkages between extension institutions and stakeholders in the development of sustainable fisheries in Lampung Province linkages between extension institutions and stakeholders in the development of sustainable fisheries in Lampung Province. In IOP Conf. Series: Journal of Physics: Conf. Series 1155 (p. 012014). http://doi.org/10.1088/1742-6596/ $1155 / 1 / 012014$ 